\title{
GILBERTUS ANGLICUS ANGLICIZED
}

\author{
by
}

\author{
FAYE MARIE GETZ*
}

BEGINNING about 1400, England experienced a remarkable increase in the amount of practical material available to readers of the vernacular. Everything from hawking to astrology found its way into English, and even Latin grammar books could explain their mysteries in the common tongue. But nowhere was this growth more striking than in the field of medicine. ${ }^{1}$ It has been estimated that the number of medical manuscripts in the vernacular was six times what it had been in the fourteenth century. ${ }^{2}$ The printing-press allowed a further acceleration in output. Paul Slack cites 153 medical titles published in England 1486-1604, and estimates that "there may have been some 166,000 medical books still in use in 1604 , one for every twenty people or so, had they been equally distributed."3

The roots of the medical text in English, then, lie in the manuscript tradition, with the printing-press satisfying an already-existing demand. These Middle English medical texts could be found alongside copies of the Latin medical classics, and scholars have seized on the difference in language to divide such works into opposing teams, with Latin, universities, physicians, and learned tradition on one side, and English, empiricism, surgeons, and popular superstition on the other: "In the latefourteenth and fifteenth centuries, the distinction between medical manuscripts in Latin and medical manuscripts in English was socially very significant. The difference in language separated the relatively few university-trained physicians like Chaucer's 'doctor of physik' from the unlatined others, specifically, the on-the-job-trained

\footnotetext{
* Faye Marie Getz, Ph.D., Wellcome Institute, 183 Euston Road, London, NW1. Research for this paper was part of a doctoral thesis at the Centre for Medieval Studies, University of Toronto ('An edition of the Middle English Gilbertus Anglicus found in Wellcome MS. 537', October 1981). The work was supervised in Toronto by Dr. A. G. Rigg and in London by Dr. C. H. Talbot and Dr. Vivian Nutton. The writer is also grateful to Mr. Eric Freeman and the staff of the Library of the Wellcome Institute for much valuable assistance and advice. Research for this thesis was funded in part by grants from the Hannah Institute for the History of Medicine, Toronto, Canada.

'See especially H. S. Bennett, 'Science and information in English writings of the fifteenth century', Modern Language Review, 1944, 39: 1-8.

${ }^{2}$ Rossell Hope Robbins, 'Medical manuscripts in Middle English', Speculum, 1970, 45: 393-415. Robbins is using material gathered from Dorothea Waley Singer's 'Survey of medical manuscripts in the British Isles dating from before the sixteenth century', Proc. R. Soc. Med., Sect. Hist. Med., 1918-1919, 12: 96-107. Her figures from the fourteenth century are 140 extant MSS, and 872 from the fifteenth. Robbins himself has examined most of her texts, and believes the data to be inflated, but the ratio correct (p. 393). Scholars estimate that approximately one in ten medieval MSS survive today.

${ }^{3}$ Paul Slack, 'Mirrors of health and treasures of poor men: the uses of the vernacular medical literature of Tudor England', in Charles Webster (editor), Health, medicine and mortality in the sixteenth century, Cambridge University Press, 1981, pp. 239-243.
} 


\section{Gilbertus Anglicus anglicized}

surgeon, barber-surgeon, apothecary, apprentice, cunning man, wise woman, lay sister in a convent, and midwife."4 This is probably true, as far as ownership of Latin medical texts by cunning men and wise women goes, but beyond that, the situation is more complex, and in any case, distinctions are less clear-cut. Graduate physicians, for example, owned fifteenth-century medical texts in English, and their less formally educated brothers had texts containing large chunks of medical material in Latin. ${ }^{5}$ As to lay ownership, an English translation of the surgery of Guy de Chauliac was made for a fifteenth-century Duke of Bedford, ${ }^{6}$ and an English recipe collection edited as the Liber de diversis medicinis was probably prepared by Robert Thornton (fl. 1440), member of a prominent Yorkshire family and a well-known translator of Latin texts, but never a medical practitioner.' The legacy of Humphrey Plantagenet, Duke of Gloucester, to Oxford University included an outstanding list of medical books in Latin, among them works of Avicenna, Bernard Gordon, Constantine Africanus, Dioscorides, Galen, Gilbertus Anglicus, Hippocrates, and Rhazes. ${ }^{8}$ Duke Humphrey's library was one of the finest collections in Europe, and it certainly cannot be deemed illustrative of the average book collector's holdings, but it does indicate that interest in "university medicine" was not solely the province of the graduate physician.

The language of a fifteenth-century medical text can tell us nothing about the professional status of its owner. In fact, possession of such a text seems to imply very little about the owner's profession at all. It would appear rather that medical literature in English or in Latin was the subject of a general interest among the literate and wealthy upper and middle classes, who could afford such books.'

If medical texts in Middle English and in Latin cannot be separated one from another by ownership, then, can they be said to represent differing medical traditions? Max Neuburger believed that vernacular medical texts were "of importance only so far as they are able to throw some light upon many hidden by-ways of medical

\footnotetext{
4 Robbins, op. cit., note 2 above, p. 394.

'Ibid., pp. 408 and 410.

- Margaret Sinclair Ogden (editor), The cyrurgie of Guy de Chauliac, Early English Text Society, Original Series 265, London, Oxford University Press, 1971.

'Margaret Sinclair Ogden (editor), The 'Liber de diversis medicinis', EETS, OS 207, London, Oxford University Press, 1938, rev. rpt. 1969.

${ }^{3}$ H. H. E. Craster, 'Index to Duke Humphrey's gifts to the old library of the university in 1439, 1441 and 1444', Bodleian Quarterly Record, 1915, 1: 131-135.

'H. E. Bell, in 'The price of books in medieval England', Library, 4th series, 1937, 17: 312-332, concluded that "in the fourteenth and fifteenth centuries manuscript books were essentially a luxury commodity" (p. 332). In the sixteenth century, however, access to printed material became more widespread as printing caused prices to drop (Slack, op. cit., note 3 above, p. 247). Would a medical practitioner have been able to afford expensive books? Charles Talbot and Eugene Hammond have said that:
}

During the fourteenth and fifteenth centuries the physicians of urban localities, especially those who came to be attached to royal households, appear to have come in increasing numbers from the new middle class. Increasingly they were university educated and subsequently qualified to enjoy the prestige which was attached to the university experience. Moreover, their incomes were in many cases adequate to permit them to accumulate property and sustain themselves in comparative affluence. The successful surgeons, even without the university hallmark, were able to live comfortably, sometimes lavishly, so munificent were their rewards. (The medical practitioners in medieval England: a biographical register, London, Wellcome Historical Medical Library, 1965, p. ix.) 
tradition."10 Yet, when the major works of Middle English medicine are catalogued, they are, in fact, translations of important and widely-circulated Latin texts. The surgeries of Lanfrank of Milan, Guy de Chauliac, and John Arderne, were all available in English by the fifteenth century, as was the medical material found in the English Bartholomaeus Anglicus. Agnus Castus, the foremost Middle English herbal, also translated a Latin text." Among uroscopies, an unpublished translation of Isaac Judaeus, found in Wellcome MSS 225 and 226,12 is particularly noteworthy. The canon of Middle English medical literature thus covered a wide range of material, a range comparable to, and in these cases, identical with, that of its Latin counterparts.

Notable by its absence from Middle English medical literature has been a translation of the work of a major medieval physician. This gap can now be supplied and the scope of the literature extended by a text copied about 1460 and found in Wellcome MS 537. ${ }^{13}$ The manuscript is a collection of short medical and astronomical tracts in Middle English and Latin, supporting one very long "top-to-toe" medical treatise in English. The first page of this text has been torn out, along with all other evidence of medieval provenance, thus leaving the identity of its author unknown. The treatise would be remarkable simply for its length and for its coherence, were it not that it is also the only known translation of the Compendium medicinae or Laurea anglicana of the physician Gilbertus Anglicus, England's first great medical writer. ${ }^{14}$

Translation, as Nancy Siraisi has observed of the thirteenth century, was often the equivalent of adaptation. ${ }^{15}$ The same is true for the translation of Gilbertus Anglicus,

\footnotetext{
${ }^{10}$ Max Neuburger, History of medicine, trans. Ernest Playfair, London, Oxford University Press, 1925, vol. 2, part 1, p. 98 .

"Robert von Fleischhacker (editor), Lanfrank's 'science of cirurgie', EETS, OS 102, London, Oxford University Press, 1894, rpt. 1973; Ogden (editor), op. cit., note 6 above; Björn Wallner has edited several sections of the Middle English Guy de Chauliac: 'The Middle English translation of Guy de Chauliac's anatomy', Lunds Universitets Ársskrift, 1964, N.F., Avd. 1, Bd. 56, Nr. 5; and 'The Middle English translation of Guy de Chauliac's treatise on fractures and dislocations', 1969, 11; 'The Middle English translation of Guy de Chauliac's treatise on wounds, part I, text', 1976, 23; 'The Middle English translation of Guy de Chauliac's treatise on wounds, part II, notes, glossary, and Latin appendix', 1979, 28; all three in Acta Universitatis Lundensis, sectio I: Theologica Juridica Humaniora. D'Arcy Power (editor), John Arderne, Treatises of fistula in ano, EETS, OS 139, London, Oxford University Press, 1910, rpt. 1968; M. C. Seymour et al. (editors), Bartholomaeus Anglicus, On the properties of things, 2 vols., London, Oxford University Press, 1975; Gösta Brodin (editor), Agnus Castus, Cambridge, Mass., Harvard University Press, 1950.

${ }_{12}$ See S. A. J. Moorat, Catalogue of western manuscripts on medicine and science in the Wellcome Historical Medical Library, vol. I: MSS written before 1650 A.D., London, Wellcome Historical Medical Library, 1962, pp. 143-144.

${ }^{13}$ The MS is described in Moorat, op. cit., note 12 above, pp. 394-395; and in my thesis, where an edition of the entire Middle English text of the Gilbertus is presented, with commentary and index of medicinal substances. All quotations from the Middle English Gilbertus will be cited according to folio numbers in Wellcome MS 537.

${ }^{14}$ Gilbertus died before 1250, and the Compendium was his chief work. For further details, see Talbot and Hammond, op. cit., note 9 above, pp. 58-60; Ernest Wickersheimer, Dictionnaire biographique des médecins en France au moyen âge, Paris, Librairie E. Droz, 1936, rpt. 1979, pp. 191-192; Charles Talbot, Medicine in medieval England, London, Oldbourne, 1967, pp. 72-87; Gundolf Keil, 'Randnotizen zu Danielle Jacquarts Wickersheimer-Supplement', Sudhoffs Archiv, 1982, 66; 176; and Henry E. Handerson, Gilbertus Anglicus, Cleveland, Ohio, Cleveland Medical Library Association, 1918.

is Nancy Siraisi, Taddeo Alderotti and his pupils, Princeton, New Jersey, Princeton University Press, 1981, p. 82.
} 
made two centuries later. Comparison of the Middle English text with its Latin counterpart shows the translator(s) at work not only rendering the material into a more accessible language, but also summarizing, abridging, expanding, and explaining those Latin words brought into English. Large chunks of material are also edited out, for instance, the first of the seven Latin sections, the one on fevers. Other sections too have been left out: skin diseases, women's diseases, and an antidotary. Whether these omissions reflect the demands of whoever commissioned the translation, the state of the Latin copy text, or the relatively tedious and convoluted nature of the contents, is difficult to determine.

More information about the translator's intentions and interests may be gained from a side-by-side comparison of parallel passages from texts in English and Latin. ${ }^{16}$ In the following description of "distempering of the liver", the translator has turned the Latin into idiomatic English, leaving very little out and employing few Latin loan words.

In the Latin:

Calide discrasie sine humoris vitio: signa sunt arsura et punctura sub dextro ypocondrio, lingue et palati siccitas, sitis continua, urina intensa rubea vel subrubea vel ultra quandoque obumbrata cum spuma crocea, citrinitas faciei, et color viridis aut emulus, habitudinis extenuatio et maxime causa prolongata; frigida prosunt, calida obsunt; frequens ventris constipatio, et egestionis paucitas, et fastidium, et sompnus brevis. Semperque in somnis os habent apertum. Adest nausea, fastidium, et in augmento oculorum, et faciei infectio, et ycteritia, et tunc sequitur universalis pruritus et scabies, cum sanguis exuritur vel incenditur, et tunc valde tabescunt. Si autem sit cum humoris vitio, aggravatio sentitur sub dextro ypocondrio. (f. $235^{\prime}$ )

In the Middle English:

Distempering of the lyuer that commeth of hete hath thes tokenes: brennyng and pricking vndir the right side, drienes of the tunge and of the roof of the mouthe, continuel thrist, the vryn is of an hie colour, the face is citryn and otherwhiles grene. Colde thingis comforten him and hote thingis noien him. He is ofte costif, and whan he shetith, it is but litil. He volateth his mete, and slepith but litil. And whan he slepith, he holdeth his mouth open. And otherwhilis, his visage and his yghen ben infecte with a yelewe colour. And then he hath a grete ycching ouer al the bodi and a scabbe. And if this distempering be of sum corrupt humour, thei felen heuynes vndir the right side. (f. 194')

In my second example, considerable modification has taken place, as the translator introduces an explanation for "spiritual member" into his advice on respiratory diseases:

Et nota quod isti pleuretici et peripleumonici et laborantes vitio spiritualium debent esse iuxta ignem carbonum a longe ut aer tepefiat inspiratus. Omnia enim actu frigida apostematibus sunt inimica. (f. $\left.178^{v}\right)$

And vnderstonde that tho that han greuaunce in her throte, either in her breest, either in her spirituel membris, that is to sey, in the membris that ben above the mydrif, as the herte and the lighte, shullen be nyghe an hoote fier, that the eyr that they resceyuen in drawing breeth be hoot, for al colde thingis ben noiful for postemes. (f. 144v)

16 The Latin Gilbertus has been printed twice: Lyons, Jacobus Sacconus for Vincentius de Portonariis, ed. Michael de Capella, 1510, which will be used for all citations in this paper; and again in Geneva, 1608. See Lynn Thorndike and Pearl Kibre (editors), A catalogue of incipits of mediaeval scientific writings in Latin, rev. and aug. ed., London, Mediaeval Academy of America, 1963, for details of MSS of Gilbertus. 
The same sort of expansion has taken place with the Latin word "ptisane", which is glossed in Middle English as "ptisane is water that barliche is soden yn" (f. 149 ). Latin "consolidativa" is also explained "consolidatiues, that is to seie, suche thingis that han vertu to souden a thing that is ykitte or broken" (f. 97 ). At times the translator employs a kind of shorthand gloss, a technique that was later to become a "stylistic trick" with Caxton: using pairs of synonyms to translate a Latin word." This can be seen in the Middle English Gilbertus, where, for instance, Latin "corrosiva" is rendered "corisiuf and freting", leaving the reader with no doubt as to what the word meant.

Explanations were not always necessary, however, as when an almost total adoption of Latin plant names into English takes place:

Debiliter dissolutiva sunt vitellum ovi, succus mente, basiliconis, sansuci, verbene, endiue, foliorum rubi, mica panis tritici tepida aspero vino vel aqua rosarum, succus feniculi, eufrasie, hedere terrestris, licium, succus prunellorum, sarcocolla, acatia, muscus, aqua vitis, mel, sanguis columbe vel pulli gallinacei, limatura auri. (f. 132')

Feble dissolutiues ben, the yolke of an egge, the iuse of myntes, of basilicon, of sansuke, verueyn, endiue, the leues of madir, hote crommes of whete brede yspringed with wyne or with rose water; also the iuse of fenel, of eufrace, of hayhoue, of licium, the iuse of sloon, sarcacolle, acacia, muske, the water of a vine, hony, the blood of a coluer or of an hen or cheken, and lymail of golde. ( $\left(f f .80^{r-y}\right.$ )

These Latin/English words are offered without a gloss, and the reader may well have been able to resort to a herbal for their definitions.

The Middle English Gilbertus is the first text of its kind to be edited, and, as such, can be expected to show a number of first usages of medical terms which either have remained in use, or have not been recorded since. A notable example of the former case is the first known English use of "gonorrhoea":

Gomorra, that is flowing of a manis sede agenis his wil, and this is of plente of blood, either of palesie of the stones, either of grete feblenes of a man that mai not withholden his sede, either it cometh for the sede is thinne and flowith oute lightli. (ff. $300^{\mathrm{v}}-301^{\mathrm{r}}$, in Latin f. $286^{\mathrm{y}}$ )

Among words that did not survive, or were supplanted by other words, the plant name "camapiteos" (Ajuga chamaepitys or ground pine) finds its only known English usage in the Middle English Gilbertus, as do such words as "folium", the leaves of the cinnamon tree; "carpobalsamum", the fruit of the balm tree; and "alipiados", the spurge laurel (Daphne laureola). Many other examples of unique occurrence are contained in this text, which serve to highlight its "experimental" nature.

One aspect of Middle English medical literature that has not yet been explored here is that most enduring and ubiquitous of all types of English medical texts, the recipe books. They are represented in Old (pre-Conquest) English by a number of texts, ${ }^{18}$ and have founded a tradition that endures up to the present day. ${ }^{19}$ The fifteenth

${ }^{17}$ Henry S. Bennett, Chaucer and the fifteenth century, Oxford, Clarendon Press, 1947, rev. rpt. 1973, p. 210. See especially 'Fifteenth-century prose', pp. 177-217, for a discussion of the development of English prose and French and Latin influences. Also see Margaret Bingham Stillwell, The awakening interest in science during the first century of printing, 1450-1550, New York, Bibliographical Society of America, 1970; and A. W. Pollard and G. R. Redgrave (editors), Short title catalogue of books printed in England, Scotland, and Ireland, 1475-1640, London, Bibliographical Society, 1946.

18 Most notable is the monumental and eccentric Leechdoms, wortcunning, and starcraft of early England, edited by Thomas Oswald Cockayne in 3 volumes, London, 1864-1866, rev. rpt. London, Holland Press, 1961. 
century has left us a number of such collections, but their lack of an obvious unity has led editors like Margaret Ogden to object that it has "been argued that the recipes represent the setting down of the details of folk procedure in a kind of spontaneous language which does not appear in ordinary literary prose." 20 Ogden has demonstrated the considerable affiliation of subject matter among various Middle English recipe books. With the Gilbertus translation, the process can be taken one step further back, to show that these texts derive from Latin exemplars: they represent folk practice no more than do the Latin copy texts from which they are excerpted.

As an illustration, a prescription from each of three fifteenth-century recipe collections will be compared to the same recipe found in the Middle English Gilbertus, and to the corresponding one in its original Latin.

In the Latin:

Item: baculi fraxinei virides ponantur in ignem, et liquor distillans a capite capiatur ad plenitudinem teste ovi, cui addantur olei communis vel butyri, duo coclearia; et de succo barbarum porrorum, coclear .i.; et de succo sempervive .ii.; de melle claro .i.; et de lacte mulieris masculum nutrientis ad masculum femine ad feminam .i. coclear. Commisceantur et colentur, et auri infundatur una gutta vel due et obturetur auris. Item sagimen anguille et succus sempervive ana comisceantur et infundantur. (f. $148^{v}$ )

In the Middle English:

Take the bowes of green asshes and ley on the fyer, and take of the water that commeth at the endes of hem the quantite of a sponeful and halfe, and put therto ii ${ }^{\circ}$ sponful of oile or of botter, and oon sponful of the iuse of synegrene, and $\mathrm{ii}^{\circ}$ sponful of hony, and a sponful of wommannes mylke that norisseth a man childe. And medle all togedre. Then put a drope or i $^{\circ}$ in the ere and stoppe it. Or take the ius of syngrene and the fatnesse of an eel yliche moche, and put therof in the eere, or the cleer grees that dropeth from a rosted eel, or castor, or gumme of yuy and mirre ymedlid with the iuse of radiche, of rwe, of wormod, or of yuy. (ff. $119^{r-v}$ )

\section{In Heinrich, Ein mittelenglisches Medizinbuch:}

Pro malo auditu: Take grene plantes of asshe, and ley hem on a brendiren and brenne hem, and kepe the water that comes out at the endes a shelfull, and the juce of cynchen thre schelfulle, and a schelfulle of eelys grece, and of the jus of the nether ende of lekes wyth the fasses a shelfulle, and a schelfulle of hony, and medle hem togedur, and boyle hem a lytul togeder, and do hem in a viol of glas, and helde ther of in the hool ere, and ley the seke on that other syde that is deef, and he shal be hool wythynn nyne tymes. And tak the wolle of a blak shepe vndre the wombe polled, and wete hit thereynne, and ley hit aboue. Item pro eodem: Take grece of an ele, and the jus of chinchen, ana, and medle hem togedre, and a litul boyle hem and do hit. Ley in to the hole ere of the seke. ${ }^{21}$

\section{In Dawson, $A$ leechbook:}

Take yonge braunchis off asshes when thai bene grene and lay hem on a brandyren on the fyre and gedir the water that commyth owt at the endys of heme an ey shall full, and the juse of the bradys of lekys an ey shell full and of the droppynge of elys, and medull all theis togeder and seith hem togeder alytell and clens hem thrugh a cloth and putt it in a glasen vessell. And when thow hast nede, put this in the hole ere of the seke mane and lat hym lygge on the sore ere. ${ }^{22}$

\footnotetext{
19 The charge that Old English medicine represents "the last stage of a process that has left no legitimate successor, a final pathological disintegration of the great system of Greek medicine”, in J. H. G. Grattan and Charles Singer's Anglo-Saxon magic and medicine, London, Oxford University Press, 1952, p. 94, has been answered by Talbot, op. cit., note 13 above, and by Linda Voigts, 'Anglo-Saxon plant remedies and the Anglo-Saxons', Isis, 1979, 70: 250-268.

${ }^{20}$ Ogden (editor), op. cit., note 7 above, p. xxvii.

${ }^{21}$ Fritz Heinrich (editor), Ein mittelenglisches Medizinbuch, Halle, Max Niemeyer, 1896, pp. 66-67.

22 Warren R. Dawson (editor), A leechbook, London, Macmillan, 1934, p. 22.
} 


\section{In Ogden, Liber:}

Take the fattnes of a blake ele and the jeuse of synegrene, elike porcyon, and putt it ofte in the hale ere and lay the on the tother... Take grene yerdis of esche and lay tham ouer a brandrethe and make a fire vnder tham and kepe the woyse that comes owt at the endis in egges schelles and tak hony and do to that woyse and do it in his ere..$^{23}$

The correspondences between the Latin Gilbertus and other Middle English recipe books are numerous, and from what has been shown here, it seems that the compilers of such recipe books did a very understandable thing. They chose a famous and enduring Latin medical textbook, and selected for themselves the most promising and useful material. As the diagnosis of most of the diseases in these books was relatively straightforward - headache, for example, no theoretical material was necessary for treatment.

These recipe books, along with the rest of Middle English medical literature, preserve largely the same material as their Latin counterparts, and may increasingly come to be seen as providing vernacular access to the best of contemporary Latin medicine, through translations, excerpts, and paraphrases. The discovery of the Middle English Gilbertus helps to demonstrate that this literature is united not only by a common language, but also by its common Latin sources. Further, Middle English medical texts were owned by a variety of people, who cannot always be identified as medical practitioners, nor can it be assumed that the difference between a Latin and a Middle English text necessarily implied ownership by people of different social status. Finally, these texts mark the beginning of a rapidly increasing effort to transform English into a language capable of accommodating technical medical material. The value of the medicine these texts represent is no longer recognized, but the language they produced remains the modern practitioner's most valuable tool.

\footnotetext{
${ }^{23}$ Ogden (editor), op. cit., note 7 above, p. 7.
} 